\title{
Photosynthetic response of cabbage in cadmium-spiked soil
}

\author{
R. BĄCZEK-KWINTA*,+, K. JUZOŃ**, M. BOREK*, and J. ANTONKIEWICZ*** \\ Department of Plant Physiology, Faculty of Agriculture and Economics, University of Agriculture in Krakow, \\ Podtużna 3, 30-239 Kraków, Poland* \\ Department of Biotechnology, F. Górski Institute of Plant Physiology, Polish Academy of Sciences, Kraków, \\ Poland $^{* *}$ \\ Department of Agricultural and Environmental Chemistry, University of Agriculture in Krakow, Mickiewicza 21, \\ 31-120 Kraków, Poland ${ }^{* * *}$
}

\begin{abstract}
Efficiency of a photosynthetic apparatus in plants growing in cadmium-spiked soil as well as plant biomass and cadmium accumulation were assessed in two cabbage cultivars (early and late) in a long-term pot experiment. Cadmium concentrations were 10 and $40 \mathrm{mg}(\mathrm{Cd})$ per kg of dry mass of soil. The early cultivar showed a dose-dependent and stable decrease in SPAD index, while in plants of the late cultivar the response was reversible and less pronounced. A huge drop in the effective quantum yield of PSII photochemistry, photochemical quenching, nonphotochemical quenching, and electron transport rate in the third week of vegetation indicated susceptibility of the early cultivar to cadmium, contrary to the late one. Fresh mass of plants of the early cultivar was diminished by both doses of Cd. For the late cultivar, there was no change in these parameters, indicating its possible usability for phytoremediation, provided the reclaimed area is fenced and protected. Particular attention should also be paid towards late cultivars cabbage farming in areas with a high $\mathrm{Cd}$ content. On the other hand, the early cultivar may serve as a bioindicator of Cd-contamination.
\end{abstract}

Additional key words: abiotic stress; Brassica oleracea; crop productivity; chlorophyll content; chlorophyll fluorescence.

\section{Introduction}

Cadmium (Cd) is one of the most toxic heavy metals. Its soil concentration depends on the parent rock but it usually exceeds acceptable limits due to anthropogenic activity (Simmons et al. 2005, Qu et al. 2013). It is supplied to soil, air, and water mainly with effluents from industry, mining, burning, and waste leakage, as well as by an application of phosphate and sewage sludge (Hsu et al. 2006, Moradi and Ehsanzadeh 2015). Mean concentration of cadmium in agricultural soils of Poland equals $c a .0 .15 \mathrm{mg} \mathrm{kg}^{-1}$ (dry mass, DM), but in regions with intense mining and smelting activities it may vary from approx. 3-40 mg kg-1(DM) (Kandziora-Ciupa et al. 2013, Bączek-Kwinta et al. 2019). In the roadside soils of Iran, cadmium content was reported to reach 2-3 $\mathrm{mg} \mathrm{kg}^{-1}$ (DM) (Samani Majd et al. 2007), and in paddy soils in China, where metal ore tailings were located, it was approx. $50 \mathrm{mg} \mathrm{kg}^{-1}$ (DM) (Zhai et al. 2008).

Due to their high mobility and toxicity even at relatively low concentrations, divalent cadmium ions are extremely dangerous not only to soil microbiota and vegetation but, through the food chain, also to humans (Anjum et al. 2016). Being highly mobile within phloem, cadmium is translocated into different plant organs, interfering with their metabolic processes (photosynthesis, respiration, nitrogen metabolism). This results in reduced growth and low biomass accumulation (Epstein and Bloom 2005, He et al. 2015).

$\mathrm{Cd}$ acts as the most potent inhibitor of photosynthetic activity (Moradi and Ehsanzadeh 2015, Sitko et al. 2017). Chlorophyll (Chl) loss or disturbances of its biosynthesis and carbon fixation by a leading photosynthetic enzyme, Rubisco, are particularly sensitive processes (Kučera et al. 2008). Cd inhibits Chl biosynthesis, enhances its degradation at heme level, hampers photochemical and carboxylation reactions of photosynthesis, and disrupts chloroplast metabolism (Wang et al. 2009, Sarangthem et al. 2011). Various studies indicated that $\mathrm{Cd}$ ions affect both donor and acceptor sites of PSII, leading to uncoupling of electron transport in the chloroplasts. In general, PSII functioning is inhibited to a much greater degree than that of PSI, and Cd exerts multiple effects on PSII (Kučera et al.

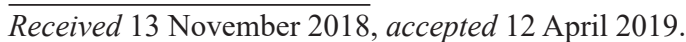

${ }^{+}$Corresponding author; e-mail: rrbaczek@cyf-kr.edu.pl

Abbreviations: BCF - bioaccumulation factor; Car - carotenoids; CF - Chl fluorescence; Chl - chlorophyll; ETR - electron transport rate; $F_{0}$ - minimal fluorescence yield at the dark-adapted state; $\mathrm{FM}$ - fresh mass; $\mathrm{F}_{\mathrm{v}} / \mathrm{F}_{\mathrm{m}}$ - maximal quantum yield of PSII photochemistry; NPQ - Stern-Volmer nonphotochemical quenching coefficient; $\mathrm{q}_{\mathrm{P}}$ - photochemical quenching coefficient; SD - standard deviation; $\Phi_{\text {PSII }}$ - effective quantum yield of PSII photochemistry.

Acknowledgements: The study was supported by European Union from European Regional Development Fund in a framework of the Innovative Economy Operational Programme 2007-2013, project 'The exploitation of white cabbage for phytoremediation and biofumigation of soils (AGROBIOKAP)', and DS 3163 research programme of University of Agriculture in Krakow. 
2008, Amirjani 2012). On the donor site, $\mathrm{Cd}$ inhibits oxygen-evolving cycle and, consequently, $\mathrm{O}_{2}$ generation. It also diminishes the number of oxygen-evolving complexes (Bazzaz and Govindjee 1974, Vassilev et al. 2004, Janeczko et al. 2005), while on the acceptor site, it inhibits electron transfer from $\mathrm{Q}_{\mathrm{A}}{ }^{-}$to $\mathrm{Q}_{\mathrm{B}}{ }^{-}$(Sigfridsson et al. 2004). Adverse effects of $\mathrm{Cd}$ are also visible in carboxylation phase of photosynthesis (Krantev et al. 2008). Stomatal conductance and index, transpiration, and net photosynthetic rate are affected, as well as enzymes of dark phase of photosynthesis (Rivera-Becerril et al. 2002, Burzyński and Żurek 2007).

Metal accumulation in plant tissues is possible due to different mechanisms, such as binding metals in the cell walls, their chelation and detoxification by cellular organic compounds (organic acids, phytochelatins), deposition in metabolically inactive organelles (vacuoles), or external tissues (Kučera et al. 2008). These mechanisms are the basis of phytoremediation, i.e., using plants to extract, sequester, and/or detoxify pollutants. Some Brassicaceae plants have huge potential for such techniques due to their hyperaccumulating properties (Milner and Kochian 2008, Mudgal et al. 2010, Tang et al. 2016, Sitko et al. 2017). Some are not hyperaccumulators but can be useful too (Radulescu et al. 2013, Goswami and Das 2015, Bernard et al. 2018). Cabbage (Brassica oleracea subsp. capitata f. alba), a well-known representative of Brassicaceae, grows rapidly and produces large biomass in a small volume. It is also perfectly adapted to the climate of many countries. Studies on bioaccumulation of metals by cabbage revealed accumulation of $\mathrm{Cd}$ in this plant growing in various locations (Sękara et al. 2005). Reports by Ciura et al. (2005), Bączek-Kwinta et al. (2011a) and Kusznierewicz et al. (2012) confirmed usefulness of white cabbage for phytoextraction in the soil contaminated with $\mathrm{Cd}$.

The parameters of fluorescence of $\mathrm{Chl} a(\mathrm{CF})$ provide in vivo assessment of the photosynthetic apparatus activity under stress. The measurements are noninvasive, and often used as an alternative for gas-exchange measurement of photosynthesis (Kouřil et al. 2003, Sitko et al. 2017). CF parameters are widely used in ecophysiological and agricultural studies (Sofo et al. 2009, Murchie and Lawson 2013). The aim of our work was to establish to what extent CF parameters and photometric assays of Chl pool (SPAD) reflect cabbage sensitivity to Cd stress. A secondary aim was to combine the above data with data on $\mathrm{Cd}$ accumulation and plant biomass to evaluate the species usefulness for phytoremediation or $\mathrm{Cd}$ bioassessment in the field. The range of $\mathrm{Cd}$ content in the soil was high and exceeded permissive values set out in framework guidelines for agriculture (Kabata-Pendias et al. 1995). A strong point of our study was its large scale and duration. We succeeded in emulating the actual field conditions much better than in hydroponics, and our report provides practical information that can be used in further field trials.

\section{Materials and methods}

Plant material: The experiment was performed in a greenhouse (phytotron) of the University of Agriculture in Kraków and involved two cabbage cultivars (Brassica oleracea ssp. capitata f. alba L.) - early cv. 'Ditmarska Najwczesniejsza' and late cv. 'Kamienna Głowa'. Seeds were treated with seed dressing $\mathrm{T}$ 75/DS/WS (70\% Thiuram), and then sown at the same time into commercial garden soil in $100-\mathrm{cm}^{3}$ volume pots. Seedlings of both cultivars grew at $5-15^{\circ} \mathrm{C} / 15-20^{\circ} \mathrm{C}$ night/day temperature and were transplanted into large pots of $10-\mathrm{dm}^{3}$ capacity at the stage of 6-8 leaves. About $10 \mathrm{~kg}$ of local soil taken from an experimental field of the University of Agriculture in Kraków, Poland, were placed in every pot. The soil granulometric composition involved: humus horizon, $19 \%$ sand, $5 \%$ coarse silt, $41 \%$ fine silt, $24 \%$ coarse silt clay, $6 \%$ clay fine silt, and $5 \%$ colloidal clay $(\mathrm{pH} 7.0)$. Further vegetation of all plants was carried out in a greenhouse, at $14 / 10 \mathrm{~h}$ (day/night) photoperiod with additional lighting on cloudy days, temperature $20-25^{\circ} \mathrm{C} / 17-20^{\circ} \mathrm{C}$ (day/night), and relative humidity $30-50 \%$. The plants were fertilized differentially according to the agricultural protocols for fast-growing early cultivars and late cultivars that grow for a long period of time: $\mathrm{N}\left(\mathrm{NO}_{3}-\mathrm{N}+\mathrm{NH}_{4}-\mathrm{N}\right)-105$ (early cultivar) and 120 (late cultivar) $\mathrm{mg} \mathrm{dm}^{-3}(\mathrm{DM}$ of soil), $\mathrm{P}\left[\mathrm{Ca}\left(\mathrm{HPO}_{4}\right)_{2}\right]-50$ and $60 \mathrm{mg} \mathrm{dm}^{-3}, \mathrm{~K}(\mathrm{KCl}, 60 \%$ potassium salt) -160 and $180 \mathrm{mg} \mathrm{dm}^{-3}$ ), respectively. The plants were irrigated daily with tap water to avoid wilting. Plant rotation towards different corners of the greenhouse was performed every 2-3 d to eliminate the effect of local changes in temperature, illumination or humidity. The plants grew for 91 (early cultivar) and $151 \mathrm{~d}$ (late cultivar).

Cd treatment: $\mathrm{Cd}$ concentrations were established based on previous experiments by Bączek-Kwinta et al. (2011a) and Kusznierewicz et al. (2012). The amounts exceeded the concentration of $4 \mathrm{mg} \mathrm{kg}^{-1}$ permissible in Poland (Regulation by the Minister of Environment 2002). Cd was added to the soil $10 \mathrm{~d}$ before planting as $\mathrm{CdSO}_{4} \cdot 8 \mathrm{H}_{2} \mathrm{O}$ (Sigma-Aldrich) dissolved in $100 \mathrm{~mL}$ of deionised water, at 10 and $40 \mathrm{mg}(\mathrm{Cd}) \mathrm{kg}^{-1}$ (DM of soil), and mixed thoroughly with the soil. The objects will be termed $\mathrm{Cd} 10$ and $\mathrm{Cd} 40$ further in the whole manuscript. Control pots contained the same soil treated with the same volume of deionised water but without Cd. Control amount of Cd was approx. $0.4 \mathrm{mg} \mathrm{kg}^{-1}$ (Kusznierewicz et al. 2012). The experiment was performed in five replications for each treatment and cultivar.

Soil and plant analysis: For metal content determination, air dried and lyophilized soil samples were mineralized in a microwave-assisted Anton Paar digestion system. Mineralization was performed at $240^{\circ} \mathrm{C}$ and $6 \mathrm{MPa}$ for 0.5 -g portions of cabbage or soil mixed with $5 \mathrm{~mL}$ of $\mathrm{HNO}_{3}+2 \mathrm{~mL}$ of $\mathrm{H}_{2} \mathrm{O}_{2}$ or $7 \mathrm{~mL}$ of $\mathrm{HNO}_{3}$ as a mineralizing solution, respectively. The acidic solutions after digestion were transferred into 25-mL PMP volumetric flasks and filled up with deionised water. A GBC SensAA atomic absorption spectrometer (GBC Scientific Equipment, Australia) furnished with deuterium lamp background correction, single element hollow cathode lamps (HCL), and air-acetylene flame was used for $\mathrm{Cd}$ determination. In the events of particularly low $\mathrm{Cd}$ content, a $G B C$ 
SavantAA $Z$ atomic absorption spectrometer ( $G B C$ Scientific Equipment, Australia) with graphite furnace atomization was employed. The sample volume injected was $10 \mu \mathrm{L}$ and the matrix modifier $(1 \%$ solution of $\mathrm{NH}_{4} \mathrm{H}_{2} \mathrm{PO}_{4}$ ) volume was $5 \mu \mathrm{L}$. $\mathrm{Cd} \mathrm{HCL}$ was used as radiation source at $228.8 \mathrm{~nm}$. A calibration curve prepared with the use of AAS/ICP grade standard stock solutions $\left(1,000 \mu \mathrm{g} \mathrm{mL} \mathrm{m}^{-1}\right.$ of Cd $)$ was applied for quantitative analysis.

Bioaccumulation factor was calculated as follows: $\mathrm{BCF}=\mathrm{C}_{\mathrm{p}} / \mathrm{C}_{\mathrm{s}}$, where $\mathrm{C}_{\mathrm{p}}$ is metal concentration in plant sample $\left[\mathrm{mg} \mathrm{kg}^{-1}\right]$ while $\mathrm{C}_{\mathrm{s}}$ is metal concentration in soil sample $\left[\mathrm{mg} \mathrm{kg}^{-1}\right]$. Plants can be accumulators if $\mathrm{BCF}>1$, when $\mathrm{BCF}=1$ there is no uptake, and if $\mathrm{BCF}<1$, then a plant can be an excluder (Baker 1981, Cluis 2004).

Relative Chl content (SPAD) and parameters of fluorescence of $\mathbf{C h l} \boldsymbol{a}(\mathbf{C F})$ : SPAD index was measured photometrically in mature, fully developed leaves with a portable Chl meter SPAD-502 Plus (Konica Minolta, Japan). Leaves at similar stage of development (third to fifth leaf from the top) were considered. Chl $a$ and $b$ absorb red but not infrared light. The meter determines absorbance in these regions, and provides numerical values of SPAD readings (maximum is 60), which are proportional to Chl content (Konica Minolta 2009). The results are expressed as 'Chl index' or 'greenness index'. The parameters of fluorescence of Chl $a$ were measured with FMS-2 fluorometer (Hansatech, United Kingdom) in the same leaves as SPAD. After 20 min of dark adaptation, a saturating light pulse $\left[10,000 \mu \mathrm{mol}\right.$ (photon) $\mathrm{m}^{-2} \mathrm{~s}^{-1}$ for $0.9 \mathrm{~s}$ ] was used to obtain $\mathrm{F}_{\mathrm{m}}$. Next, the leaf was irradiated with actinic light $\left[1,500 \mu \mathrm{mol}\left(\right.\right.$ photon) $\left.\mathrm{m}^{-2} \mathrm{~s}^{-1}\right]$ for $270 \mathrm{~s}$.
Then, the saturating light pulse was used again. The source of a modulation beam (duration pulses $1.8 \mu \mathrm{s}, 2.3 \mathrm{kHz}$ ) was an amber LED [peak wavelength of $594 \mathrm{~nm}$, PPFD ca. $0.05 \mu \mathrm{mol}$ (photon) $\mathrm{m}^{-2} \mathrm{~s}^{-1}$. Actinic and pulse irradiations were provided by a halogen lamp $(20 \mathrm{~W})$. The signal detector was a PIN photodiode with a long-pass filter $(>700 \mathrm{~nm})$, and the sampling rate was $10-20 \mathrm{kHz}$ (depending on the instrument mode). Parameters of the maximum photochemical efficiency of PSII $\left(\mathrm{F}_{\mathrm{v}} / \mathrm{F}_{\mathrm{m}}\right)$, the quantum efficiency of photochemical reactions in PSII $\left(\Phi_{\mathrm{PSII}}\right)$, the photochemical quenching of PSII $\left(\mathrm{q}_{\mathrm{P}}\right)$, the nonphotochemical quenching (NPQ), and the efficiency of electron flow rate (ETR) were automatically calculated according to Genty et al. (1989) and Schreiber et al. (1986). Stern-Volmer nonphotochemical quenching was expressed as NPQ $=\left(F_{m}-F_{m}{ }^{\prime}\right) / F_{m}{ }^{\prime}($ Bilger and Björkman 1991).

Statistical analysis: To investigate normality of distribution, Kolmogorov-Smirnov's test was used. Then analysis of variance $(A N O V A)$ with repeated measurements and Duncan's test $(n=5, P=0.05)$ were performed. The differences were considered significant if $P$ was at least $\leq 0.05$. All the analyses were carried out using Microsoft Office Excel 2007 and Statistica 12.0 package (SPSS, USA).

\section{Results}

SPAD and CF parameters: SPAD index depended primarily on the growth stage ('date' factor) and cultivar (Fig. 1A,B; Table 1). It increased with time and plants of the late cultivar showed higher values of the parameter than those of the early one. Both the 'treatment' factor

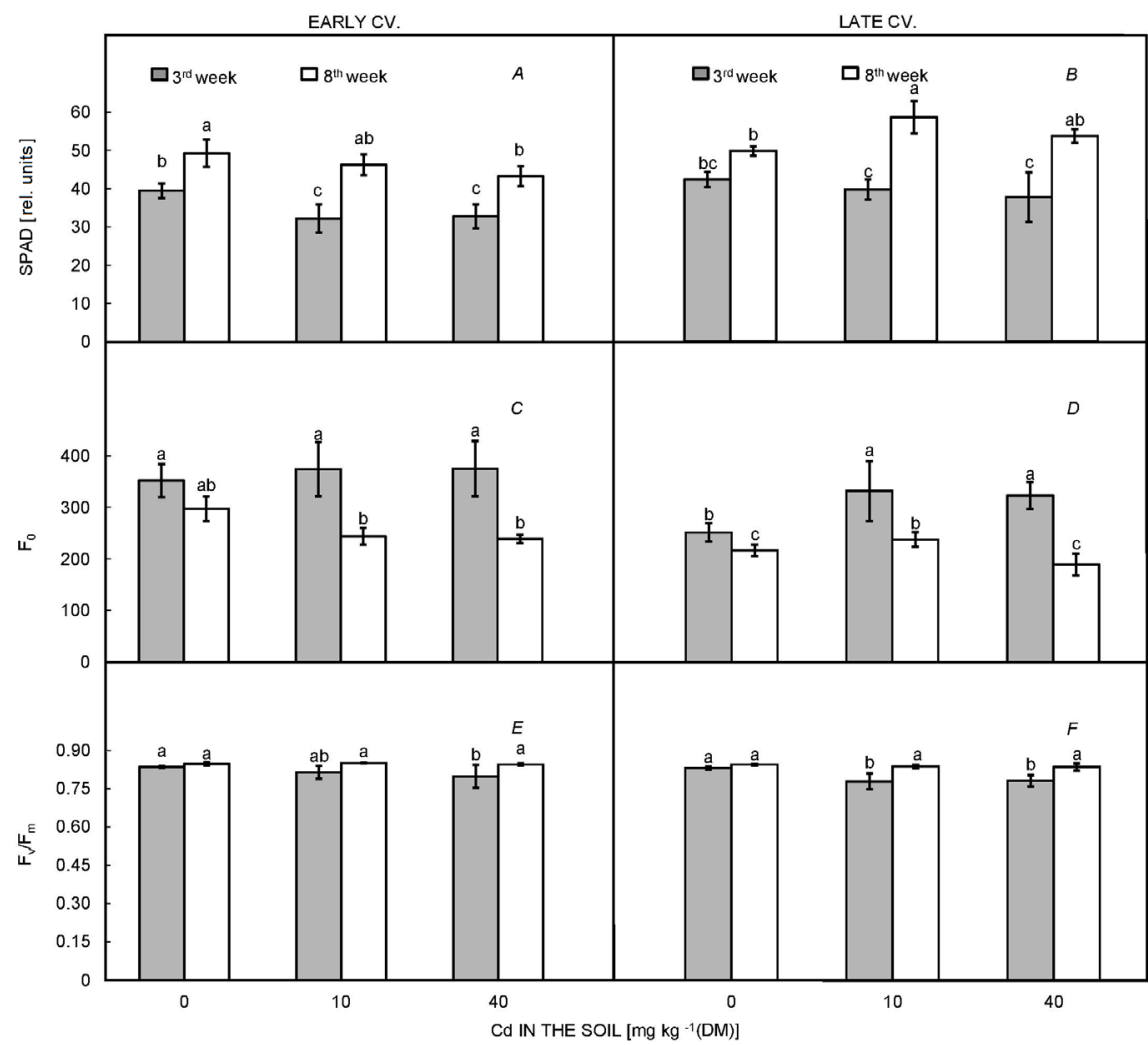

Fig. 1. The influence of cadmium on SPAD values $(A, B)$ and chlorophyll fluorescence $(\mathrm{CF})$ parameters $(C-F)$ of leaves of white cabbage at the $3^{\text {rd }}$ and $8^{\text {th }}$ weeks of growth. SPAD - Soil-Plant Analyses Development (greenness index), $\mathrm{F}_{0}$ - minimal fluorescence yield at the dark-adapted state, $\mathrm{F}_{\mathrm{v}} / \mathrm{F}_{\mathrm{m}}$ - photochemical efficiency of PSII at the darkadapted state. $n=5$, means labelled with the same letter are not significantly different $(P<0.05$; Duncan's test). 


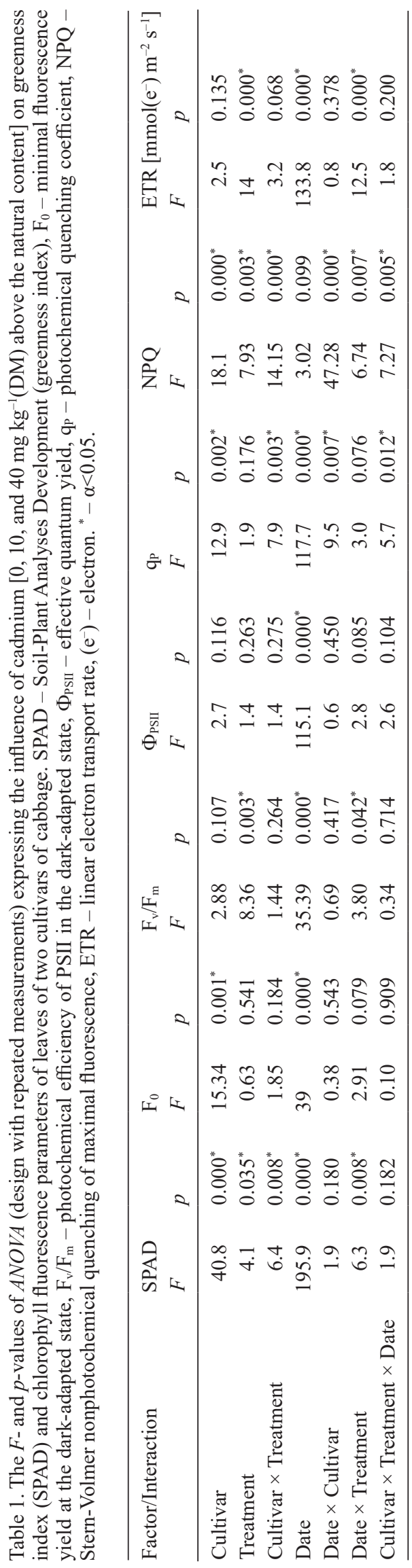

and 'cultivar' $x$ 'treatment' interactions were significant, which means a decrease of the values for the early cultivar, but no significant decrease for the late one (Table 1, Fig. $1 A, B)$. 'Date' $\times$ 'treatment' interaction demonstrated Cd-triggered drop or a tendency in both cultivars at the third week that ceased (and/or even turned into an increase) during further cultivation (eighth week).

We saw no impact of $\mathrm{Cd}$ on minimal fluorescence in the dark-adapted state $\left(\mathrm{F}_{0}\right)$ (Table 1). Cultivar dependence of $F_{0}$ was manifested as higher values in plants of the early cultivar (Table 1, Fig. 1C). Time-scale analysis revealed a similar course of $\mathrm{F}_{0}$ decrease in all plants (Fig. 1C,D; Table 2).

The values of maximal quantum yield of PSII photochemistry $\left(\mathrm{F}_{\mathrm{v}} / \mathrm{F}_{\mathrm{m}}\right)$ depended on the 'treatment', 'date', and their interaction (Table 1). Cd40 (early cultivar) and Cd10 and $\mathrm{Cd} 40$ (late cultivar) caused a decrease in $\mathrm{F}_{\mathrm{v}} / \mathrm{F}_{\mathrm{m}}$ in the third week. Then, the values increased to the control level which remained unchanged over time (Table 1, Fig. 1E,F).

The effective quantum yield of PSII photochemistry $\left(\Phi_{\text {PSII }}\right)$ depended on the 'date' only, which means the values increased in time irrespectively of the cultivar or treatment (Table 1, Fig. 2A,B). However, Duncan's test revealed the difference between Cd-treated plants and the control of the early cultivar (Fig. 2A).

In the case of photochemical quenching $\left(\mathrm{q}_{\mathrm{P}}\right)$, ANOVA indicated significance of all factors but 'treatment' and 'date' $\times$ 'treatment' (Table 1, Fig. 2C,D). Hence, mean values of $\mathrm{q}_{\mathrm{P}}$ were lower for the early than for the late cultivar ('cultivar' factor), due to a sharp decrease experienced in the third week by the early plants $v s$. control ('cultivar' $\times$ 'treatment'). Similarly to previously described parameters, we saw an increase in $\mathrm{q}_{\mathrm{p}}$ for the eighth week as compared to the third week ('date' significant, Table 1, and the Duncan's test, Fig. 2C,D).

For NPQ, ANOVA indicated the impact of all factors except for 'date' (Table 2). As in the case of $\mathrm{q}_{\mathrm{P}}$, plants of the early cultivar demonstrated lower NPQ than those of the late one (Fig. 2E,F; respectively). This was caused mostly by a large drop in the presence of Cd (Fig. 2E), as the control values of NPQ were similar for both cultivars (Fig. 2E,F).

Electron flow rate (ETR) depended on the 'treatment', 'date', and their interaction (Table 1). In the plants of the early cultivar (Cd40), ETR diminished by one third of control in the third week but increased during the eighth week and doubled that of the control (Fig. 2G). For plants of the late cultivar, the ETR pattern during the third week resembled that of $\Phi_{\mathrm{PSII}}$ and $\mathrm{q}_{\mathrm{P}}$, and during the eighth week the values increased (Fig. $2 G, H$ ).

Plant biomass and Cd accumulation: Head size of the plants in the early cultivar diminished in the presence of both doses of $\mathrm{Cd}$ to similar extent (80-90\% of control), while in the late cultivar similar fresh mass was obtained irrespectively of the treatment (Table 2).

Bioavailable $\mathrm{Cd}$ and bioaccumulation factor $(\mathrm{BCF})$ were similar in both controls (Table 2). For Cd10 treatment, bioavailable $\mathrm{Cd}$ equaled 1,357 and $1,168 \%$ of the control for the early and late cultivar, respectively. Interestingly, 
Table 2. Biomass of heads and cadmium accumulation by cabbage grown in unspiked soil and the soil spiked with cadmium. The natural content of cadmium was approx. $0.4 \mathrm{mg} \mathrm{kg}^{-1}(\mathrm{DM})$. The early cultivar was grown for $91 \mathrm{~d}$, the late one for $151 \mathrm{~d}$. The data of different treatments within the cultivar marked by the same letter are not significantly different at $P<0.05$; Duncan's test. Cd treatment - content of $\mathrm{Cd}$ in the soil above the natural value, FM - fresh mass, DM - dry mass.

\begin{tabular}{|c|c|c|c|c|c|c|}
\hline \multirow[t]{2}{*}{$\begin{array}{l}\text { Cd treatment } \\
{\left[\mathrm{mg} \mathrm{kg}^{-1}(\mathrm{DM})\right]}\end{array}$} & \multicolumn{2}{|c|}{$\begin{array}{l}\text { Biomass of heads }[\mathrm{kg} \mathrm{FM}] \\
\text { and in relation to control [\%] }\end{array}$} & \multicolumn{2}{|c|}{$\begin{array}{l}\text { Bioavailable } \mathrm{Cd}\left[\mathrm{mg} \mathrm{kg}^{-1}(\text { head } \mathrm{DM})\right] \\
\text { and in relation to control [\%] }\end{array}$} & \multicolumn{2}{|c|}{$\begin{array}{l}\text { Bioaccumulation factor } \\
{\left[\mathrm{mg} \mathrm{Cd}\left(\text { heads) } \mathrm{mg} \mathrm{Cd}(\text { soil })^{-1}\right]\right.} \\
\text { and in relation to control }[\%]\end{array}$} \\
\hline & Early cultivar & Late cultivar & Early cultivar & Late cultivar & Early cultivar & Late cultivar \\
\hline 0 & $\begin{array}{l}0.737 \pm 0.081^{\mathrm{a}} \\
100 \%\end{array}$ & $\begin{array}{l}1.215 \pm 0.095^{\mathrm{a}} \\
100 \%\end{array}$ & $\begin{array}{l}0.37 \pm 0.01^{\mathrm{a}} \\
100 \%\end{array}$ & $\begin{array}{l}0.38 \pm 0.16^{\mathrm{a}} \\
100 \%\end{array}$ & $\begin{array}{l}1.11 \pm 0.26^{\mathrm{a}} \\
100 \%\end{array}$ & $\begin{array}{l}1.19 \pm 0.33^{\mathrm{a}} \\
100 \%\end{array}$ \\
\hline 10 & $\begin{array}{l}0.609 \pm 0.070^{\mathrm{b}} \\
82 \%\end{array}$ & $\begin{array}{l}1.441 \pm 0.152^{\mathrm{a}} \\
119 \%\end{array}$ & $\begin{array}{l}5.02 \pm 0.35^{\mathrm{b}} \\
1,357 \%\end{array}$ & $\begin{array}{l}4.44 \pm 0.83^{\mathrm{b}} \\
1,168 \%\end{array}$ & $\begin{array}{l}0.49 \pm 0.04^{\mathrm{b}} \\
44 \%\end{array}$ & $\begin{array}{l}0.44 \pm 0.04^{\mathrm{b}} \\
37 \%\end{array}$ \\
\hline 40 & $\begin{array}{l}0.654 \pm 0.070^{\mathrm{b}} \\
88 \%\end{array}$ & $\begin{array}{l}1.219 \pm 0.231^{\mathrm{a}} \\
100 \%\end{array}$ & $\begin{array}{l}8.56 \pm 0.90^{\mathrm{c}} \\
2,314 \%\end{array}$ & $\begin{array}{l}18.7 \pm 1.70^{\mathrm{c}} \\
4,921 \%\end{array}$ & $\begin{array}{l}0.21 \pm 0.02^{\mathrm{c}} \\
19 \%\end{array}$ & $\begin{array}{l}0.46 \pm 0.06^{\mathrm{b}} \\
39 \%\end{array}$ \\
\hline
\end{tabular}

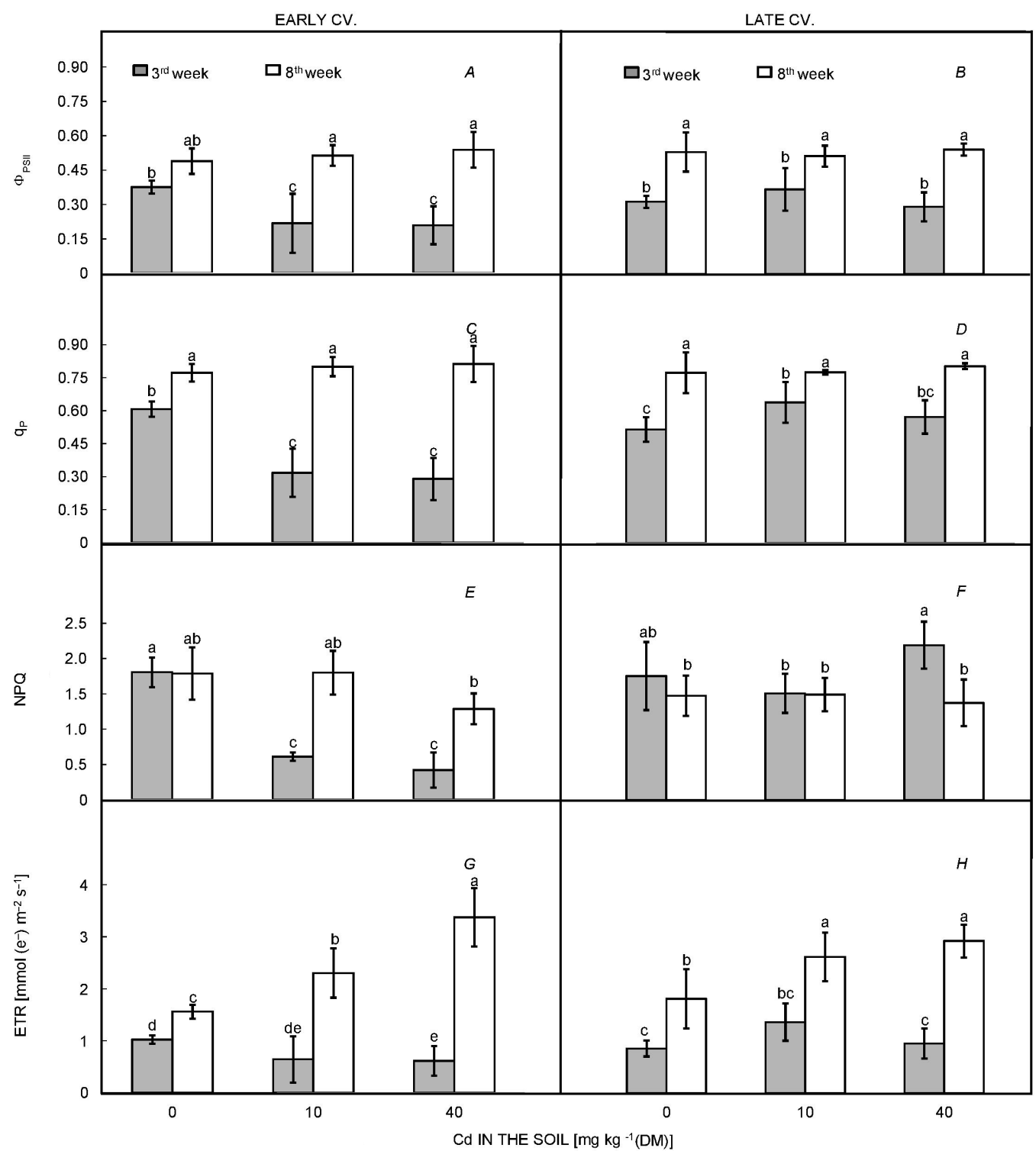

Fig. 2. The influence of cadmium on chlorophyll fluorescence parameters of leaves of white cabbage at the $3^{\text {rd }}$ and $8^{\text {th }}$ weeks of growth. $\Phi_{\mathrm{PSII}}$ - effective quantum yield, $\mathrm{q}_{\mathrm{P}}$ - photochemical quenching coefficient, NPQ - Stern-Volmer nonphotochemical quenching of maximal fluorescence, ETR - linear electron transport rate. $n=5$, means labelled with the same letter are not significantly different $(P<0.05 ;$ Duncan's test $)$. 
the $\mathrm{BCF}$ values diminished in plants exposed to $\mathrm{Cd} 10$ (44 and $37 \%$ of respective control). For Cd40, a great increase in bioavailable Cd occurred (2,314 and 4,921\% of respective controls), but $\mathrm{BCF}$ was lower than for $\mathrm{Cd} 10$ and the values were 19 and $39 \%$ for early and late cultivar, respectively (Table 2).

\section{Discussion}

SPAD and CF parameters: The greenness index measured with different devices is a popular parameter used in studies on plant response to different stress factors (Haripriya Anand and Byju 2008, Sękara et al. 2016, Bączek-Kwinta et al. 2019). The method is noninvasive, which was important in the described experiment especially at the beginning of vegetation (in the third week). Moreover, the measurements can be taken in the field, and we were interested whether the values of SPAD matched those of $\mathrm{CF}$ depending on $\mathrm{Cd}$ concentration. Our results revealed a stable downward trend in SPAD index in the early cultivar for both $\mathrm{Cd}$ doses, indicating diminished pool of Chl. Even though we did not perform chemical determination of Chl, its loss and mechanisms of this loss are well known in the case of cadmium stress. These mechanisms include Chl degradation or disturbances of its synthesis or inhibition of cell division and replication of chloroplasts (Baryla et al. 2001, Nikolić et al. 2008). $\mathrm{Cd}$ inhibits reduction of protochlorophyllide and synthesis of aminolevulinic acid (ALA), a specific precursor of Chl biosynthesis (Bhattacharjee and Mukherjee 2003, Sarangthem et al. 2011). The decrease in Chl content can also be due to increased iron uptake in the presence of $\mathrm{Cd}$. Iron substitutes magnesium and heme is produced instead of Chl (Zhou and Qiu 2005).

Greenness index often inversely corresponds with $\mathrm{F}_{0}$, namely, higher greenness index and chemically assayed Chl content correlate with lower $\mathrm{F}_{0}$ values (Baker 2008, Borek et al. 2016). The downward trend in SPAD readings for the late cultivar ceased over time, and the time course of changes in $\mathrm{F}_{0}$ was opposite to that of SPAD. We can therefore assume that $\mathrm{Chl}$ biosynthesis was restored in these plants contrary to those of the early cultivar.

A slight decline in $\mathrm{F}_{\mathrm{v}} / \mathrm{F}_{\mathrm{m}}$ in the third week with increasing concentration of $\mathrm{Cd}$ indicated stress exposure of the photosynthetic apparatus (Muniz et al. 2014, Moradi and Ehsanzadeh 2015). However, the ratio increased over time, so we can expect the response is reversible and plants are capable of acclimating to such conditions. Temporary declines of $F_{v} / F_{m}$ and SPAD suggest that Cd not harmfully affected the symplast which implies vacuolar sequestration mechanisms and protection against Cd-triggered oxidative stress (Carrier et al. 2003, Nikolić et al. 2008, Mohamed et al. 2012). However, even distinct changes in $\mathrm{F}_{\mathrm{v}} / \mathrm{F}_{\mathrm{m}}$ may be insufficient to accurately assess functioning of the photosynthetic apparatus. Therefore, it is necessary to take other values into account (Bączek-Kwinta et al. 2011b, Borek et al. 2016).

Low $\Phi_{\text {PSII }}$ values in the early cultivar plants grown in Cd-contaminated soil confirmed disturbances of photosynthetic processes and diminished ratio of quanta used in photochemical processes to the total number of absorbed PAR quanta (Genty et al. 1989). This may correlate with diminished rate of $\mathrm{CO}_{2}$ uptake in the leaves and result directly in lower carbon assimilation (Kalaji et al. 2014).

A decrease in q values in the plants of the early cultivar confirmed their sensitivity to $\mathrm{Cd}$ and indicated a closure of the PSII reaction centers during photosynthesis saturated by actinic radiation (Maxwell and Johnson 2000).

The nonphotochemical quenching of PSII (NPQ) comprises the processes that convert part of the energy absorbed in the light phase of photosynthesis into heat (Maxwell and Johnson 2000). Intensification of these processes occurs in the presence of very intense light or other stress factors. The increase in NPQ reflects energy dissipation by heat via the carotenoids (Car) of the xanthophyll cycle (VAZ) and other Cars, as well as by conformational changes of PSII antennae (LHC) (Havaux and Kloppstech 2001, Szabó et al. 2005, Sofo et al. 2009). In this study, we saw a decrease in NPQ in the third week in the plants of the early cultivar. This was surprising, because if photochemical quenching declined, the absorbed energy should have been dissipated, mainly by the Cars (Pogson and Rissler 2000). The reason might be a reduced synthesis of these pigments, which is typical of Cd stress (Jiang et al. 2013, Cheng et al. 2016, Paunov et al. 2018).

Similarly to the previously discussed parameters, ETR declined in the third week in the early cultivar. This suggests a disruption in functionality of the thylakoidbound electron transport chain from PSII to PSI (Papadakis et al. 2007). Considering the above-described declines, it can be inferred that the photosynthetic apparatus of plants of the early cultivar was under considerable stress at the beginning of the growing season. The plants of the late cultivar showed a weaker response. Such differences result probably from faster growth of the early cultivar plants $v s$. those representing the late one (data not shown). ETR was the only parameter, the values of which in the eighth week increased along with growing $\mathrm{Cd}$ concentrations in soil (compared to control plants). This suggests intensification of electron flow between PSII and PSI. It is also possible that other processes involving electrons, such as photorespiration, Mehler reaction, and reduction of nitrates occurred (Fracheboud and Leipner 2003).

Overall, the $\mathrm{CF}$ results confirmed that $\mathrm{Cd}$ affected the photosynthetic apparatus in a different way in both cultivars, which was reflected in different pattern of changes in studied parameters. The parameters which revealed distinct changes in response to $\mathrm{Cd}$ treatment were $\Phi_{\mathrm{PSII}}, \mathrm{q}_{\mathrm{P}}$, NPQ, and ETR, therefore they can be used as markers of the physiological changes induced by $\mathrm{Cd}$ treatment.

Plant biomass and $\mathbf{C d}$ accumulation: Previous reports (Bączek-Kwinta et al. 2011a, Kusznierewicz et al. 2012) showed that cabbage plants, especially those of the late cultivar, are capable of growing in Cd-spiked soil, tolerating $\mathrm{Cd}$, and accumulating this element in their heads. This study corroborated these claims. Despite large amount of soil used in the experiment, FM of all heads was rather low, which is typical of greenhouse conditions (data not shown). In the field, the yield of 150 to 300 tons per hectare is 
achievable, with estimated output of Cd up to 180 to $360 \mathrm{~g}$ per ha, according to Kusznierewicz et al. (2012). When we compare phytoremediative properties of cabbage to other edible plants, the potential uptake of Cd by cabbage seems higher than of, e.g., wheat or Cd-hyperaccumulator chard (Beta vulgaris L. var. cicla) (Shumaker and Begonia 2005, Song et al. 2012). Yet, it depends on the cultivar. The early one accumulated less $\mathrm{Cd}$ than the late one, and its biomass was lower. Moreover, smaller bioaccumulation factor indicates that the plants did not allow $\mathrm{Cd}$ to distribute in heads, so either $\mathrm{Cd}$ uptake from the soil was limited, or its accumulation in roots occurred to a bigger extent than in the plants of the late cultivar (Baker 1981, Cluis 2004). Kusznierewicz et al. (2012) claimed that since plants of the early cultivar may be planted twice per agricultural season, the phytoremediation results may be similar to those of the late cultivar, even though such a solution would be more cost- and labor-consuming. Metal uptake may depend on soil composition and pH (McBride 1989, Melo et al. 2014, Bernard et al. 2018); hence, implementation of proper agricultural treatments (such as intense fertilization of the late cultivars) is necessary. An environmental issue should be also considered, namely potential transfer of $\mathrm{Cd}$ from the spiked plants into small herbivores leading to further release of $\mathrm{Cd}$ to the trophic chain (Hladun et al. 2015). To prevent the entrance of larger animals and humans, the area subjected to phytoremediation should be fenced and clearly labelled. Particular attention should also be paid towards agricultural crops of late cabbage in areas with high $\mathrm{Cd}$ content.

Conclusion: In the presence of $\mathrm{Cd}$, the photosynthetic apparatus in the early cultivar of cabbage operated less efficiently than in the late one. The changes occurred rapidly, and they were reflected in the yield as well as diminished biomass of heads. This, together with lower bioaccumulation factor of $\mathrm{Cd}$ in the early cultivar plants, allows us to identify the early cultivar as useful for the bioassessment of soil contamination. The late cultivar can be recommended for phytoremediation of Cd-contaminated soils, due to less intense response of the plants reflected by high head biomass and high bioaccumulation factor. The parameters of fluorescence of $\mathrm{Chl} a$ considerably affected by $\mathrm{Cd}$ treatment involved $\Phi_{\mathrm{PSII}}, \mathrm{q}_{\mathrm{P}}, \mathrm{NPQ}$, and ETR, hence they may be the markers of Cd-triggered physiological changes in cabbage plants.

\section{References}

Amirjani M.R.: Effects of cadmium on wheat growth and some physiological factors. - Int. J. Forest Soil Eros. 2: 50-58, 2012.

Anjum S.A., Tanveer M., Hussain S. et al.: Osmoregulation and antioxidant production in maize under combined cadmium and arsenic stress. - Environ. Sci. Pollut. R. 23:11864-11875, 2016.

Bączek-Kwinta R., Antonkiewicz A., Łopata-Stasiak A., Kępka W.: Smoke compounds aggravate stress inflicted on Brassica seedlings by unfavourable soil conditions. - Photosynthetica 57: 1-8, 2019.

Bączek-Kwinta R., Bartoszek A., Kusznierewicz B.: Physiological response of plants and cadmium accumulation in heads of two cultivars of white cabbage. - J. Elementol. 16: 355-364, 2011a.

Bączek-Kwinta R., Kozieł A., Seidler-Łożykowska K.: Are the fluorescence parameters of German chamomile leaves the first indicators of the anthodia yield in drought conditions? Photosynthetica 49: 87-97, 2011b.

Baker A.J.M.: Accumulators and excluders - strategies in the response of plants to heavy metals. - J. Plant Nutr. 3: 643-654, 1981.

Baker N.R.: Chlorophyll fluorescence: a probe of photosynthesis in vivo. - Annu. Rev. Plant Biol. 59: 89-113, 2008.

Baryla A., Carrier P., Franck F. et al.: Leaf chlorosis in oilseed rape plants (Brassica napus) grown on cadmium-polluted soil: causes and consequences for photosynthesis and growth. Planta 212: 696-709, 2001.

Bazzaz M.B., Govindjee: Effect of cadmium nitrate on the spectral characteristic and light reactions of chloroplasts. Environ. Lett. 6: 1-12, 1974.

Bernard F., Dumez S., Lemière S.: Impact of cadmium on forage kale (Brassica oleracea var. viridis cv „Prover”) after 3-,10and 56-day exposure to a Cd-spiked field soil. - Environ. Sci. Pollut. R.: https://doi.org/10.1007/s11356-018-1636-8, 2018.

Bhattacharjee S., Mukherjee A.K.: Heavy metals alter photosynthetic pigment profiles as well as activities of Chlase and 5-aminolevulinic acid dehydratase (ALAD) in Amaranthus lividus seedlings. - J. Environ. Biol. 24: 395-399, 2003.

Bilger W., Björkman O.: Temperature-dependence of violaxanthin deepoxidation and nonphotochemical fluorescence quenching in intact leaves of Gossypium hirsutum L. and Malva parviflora L. - Planta 184: 226-234, 1991.

Borek M., Bączek-Kwinta R., Rapacz M.: Photosynthetic activity of variegated leaves of Coleus $\times$ hybridus Hort. cultivars characterised by $\mathrm{Chl}$ fluorescence techniques. Photosynthetica 54: 331-339, 2016.

Burzyński M., Żurek A.: Effects of copper and cadmium on photosynthesis in cucumber cotyledons. - Photosynthetica 45: 239-244, 2007.

Carrier P., Baryla A., Havaux M.: Cadmium distribution and microlocalization in oilseed rape (Brassica napus) after longterm growth on cadmium-contaminated soil. - Planta 216: 939-950, 2003.

Cheng S., Ren F., Grosse W., et al:. Effects of cadmium on chlorophyll content, photochemical efficiency, and photosynthetic intensity of Canna indica Linn., - Int. J. Phytoremed. 4: 239-246, 2002.

Ciura J., Poniedziałek M., Sękara A., Jędrszczyk E.: The possibility of using crops as metal phytoremediants. - Pol. J. Environ. Stud. 14: 17-22, 2005.

Cluis C.: Junk-greedy greens: phytoremediation as a new option for soil decontamination. - BioTeach J. 2: 61-67, 2004.

Epstein E., Bloom A.J.: Mineral Nutrition of Plants: Principles and Perspectives. Pp. 380. Sinauer Associates, Inc., Sunderland 2005.

Fracheboud Y., Leipner J.: The application of chlorophyll fluorescence to study light, temperature, and drought stress. - In: DeEll J.R., Toivonen P.M.A. (ed.): Practical Applications of Chlorophyll Fluorescence in Plant Biology. Pp. 125-150. Springer, New York 2003.

Genty B., Briantais J.M., Baker N.R.: The relationship between the quantum yield of photosynthetic electron transport and quenching of Chl fluorescence. - BBA-Gen. Subjects 990: 87-92, 1989.

Goswami S., Das S.: A study on cadmium phytoremediation potential of Indian mustard, Brassica juncea. - Int. J. Phytoremediat. 17: 583-588, 2015.

Haripriya Anand M.H., Byju G.: Chlorophyll meter and leaf 
colour chart to estimate $\mathrm{Chl}$ content, leaf colour, and yield of cassava. - Photosynthetica 46: 511-516, 2008.

Havaux M., Kloppstech K.: The protective functions of carotenoid and flavonoid pigments against excess visible radiation at chilling temperature investigated in Arabidopsis $n p q$ and $t t$ mutants. - Planta 213: 953-966, 2001.

He S., He Z., Yang X., et al.: 2015. Soil biogeochemistry, plant physiology, and phytoremediation of cadmium-contaminated soils. - Adv. Agron. 134: 135-225, 2015.

Hladun K.R., Parker D.R., Trumble J.T.: Cadmium, copper, and lead accumulation and bioconcentration in the vegetative and reproductive organs of Raphanus sativus: Implications for plant performance and pollination. - J. Chem. Ecol. 41: 386-395, 2015.

Hsu Y.T., Kuo M.C., Kao C.H.: Cadmium-induced ammonium ion accumulation of rice seedlings at high temperature is mediated through abscisic acid. - Plant Soil 287: 267-277, 2006.

Janeczko A., Kościelniak J., Pilipowicz M. et al.: Protection of winter rape photosystem II by 24-epibrassinolide under cadmium stress. - Photosynthetica 43: 293-298, 2005.

Jiang H.P., Gao B.B., Li W.H. et al.: Physiological and biochemical responses of Ulva prolifera and Ulva linza to cadmium stress. - Sci. World J. 3: 94-106, 2013.

Kabata-Pendias A., Piotrowska M., Motowicka-Terelak T. et al.: Basis for the Assessment of Chemical Contamination of Soil Heavy Metals, Sulfur and PAHs. Pp. 41. State Inspectorate for Environmental Protection, Warsaw 1995.

Kalaji H.M., Schansker G., Ladle R.J. et al.: Frequently asked questions about in vivo $\mathrm{Chl}$ fluorescence: practical issues. Photosynth. Res. 122: 121-158, 2014.

Kandziora-Ciupa M., Ciepał R., Nadgórska-Socha A., Barczyk G.: A comparative study of heavy metal accumulation and antioxidant responses in Vaccinium myrtillus L. leaves in polluted and non-polluted areas. - Environ. Sci. Pollut. R. 20: 4920-4932, 2013.

KONICA MINOLTA: Chlorophyll meter SPAD-502Plus Instruction Manual, Japan 2009.

Kouřil R., Lazár D., Lee H. et al.: Moderately elevated temperature eliminates resistance of rice plants with enhanced expression of glutathione reductase to intensive photooxidative stress. Photosynthetica 41: 571-578, 2003.

Krantev A., Yordanova R., Janda T. et al.: Treatment with salicylic acid decreases the effect of cadmium on photosynthesis in maize plants. - J. Plant Physiol. 165: 920-931, 2008.

Kučera T., Horáková H., Šonská A.: Toxic metal ions in photoautotrophic organisms. - Photosynthetica 46: 481-489, 2008.

Kusznierewicz B., Bączek-Kwinta R., Bartoszek A. et al.: The dose-dependent influence of zinc and cadmium contamination of soil on their uptake and glucosinolate content in white cabbage (Brassica oleracea var. capitata f. alba). - Environ. Toxicol. Chem. 31: 2482-2489, 2012.

Maxwell K., Johnson G.N.: Chlorophyll fluorescence a practical guide. - J. Exp. Bot. 51: 659-668, 2000.

McBride M.B.: Reactions controlling heavy metal solubility in soils. - In: Stewart B.A. (ed.): Advances in Soil Science. Pp. 1-56. Springer, New York 1989.

Melo L.C.A., da Silva E.B., Alleoni L.R.F.: Transfer of cadmium and barium from soil to crops grown in tropical soils. R. Bras. Ci. Solo 38: 1939-1949, 2014.

Milner M.J., Kochian L.V.: Investigating heavy-metal hyperaccumulation using Thlaspi caerulescens as a model system. Ann. Bot. 102: 3-13, 2008.

Mohamed A.A., Castagna A., Ranieri A., Sanità di Toppi L.: Cadmium tolerance in Brassica juncea roots and shoots is affected by antioxidant status and phytochelatin biosynthesis. -
Plant Physiol. Bioch. 57: 15-22, 2012.

Moradi L., Ehsanzadeh P.: Effects of Cd on photosynthesis and growth of safflower (Carthamus tinctorius L.) genotypes. Photosynthetica 53: 506-518, 2015.

Mudgal V., Madaan N., Mudgal A.: Heavy metals in plants: Phytoremediation. Plants used to remediate heavy metal pollution. - Agric. Biol. J. N. Am. 1: 40-46, 2010.

Muniz C.R, Freire F.C.O, Viana F.M.P et al.: Monitoring cashew seedlings during interactions with the fungus Lasiodiplodia theobromae using Chl fluorescence imaging. - Photosynthetica 52: 529-537, 2014.

Murchie E.H., Lawson T.: Chlorophyll fluorescence analysis: a guide to good practice and understanding some new applications. - J. Exp. Bot. 64: 3983-3998, 2013.

Nikolić N., Kojić D., Pilipović A. et al.: Responses of hybrid poplar to cadmium stress: photosynthetic characteristics, cadmium and proline accumulation, and antioxidant enzyme activity. - Acta Biol. Cracov. Bot. 50: 95-103, 2008.

Papadakis I.E., Giannakoula A., Antonopoulou C.P. et al.: Photosystem II activity of Citrus volkameriana (L.) leaves as affected by Mn nutrition and irradiance. - Photosynthetica 45: 208-213, 2007.

Paunov M., Koleva L., Vassilev A. et al.: Effects of different metals on photosynthesis: Cadmium and zinc affect chlorophyll fluorescence in durum wheat. - Int. J. Mol. Sci. 19: 787, 2018.

Pogson B.J., Rissler H.M.: Genetic manipulation of carotenoid biosynthesis and photoprotection. - Philos. T. R. Soc. B 355: 1395-1403, 2000.

Qu G., Tong Y., Gao P. et al.: Phytoremediation potential of Solanum nigrum L. under different cultivation protocols. B. Environ. Contam. Tox. 91: 306-309, 2013.

Radulescu C., Stihi C., Popescu I.V. et al.: Heavy metal accumulation and translocation in different parts of Brassica oleracea L. - Rom. J. Phys. 58: 1337-1354, 2013.

Regulation by the Minister of Environment dated 9 September 2002. Official Gazette No. 165, Pos. $1359^{\text {th }}$. [In Polish]

Rivera-Becerril F., Calantzis C., Turnau K. et al.: Cadmium accumulation and buffering of cadmium-induced stress by arbuscular mycorrhiza in three Pisum sativum L. genotypes. J. Exp. Bot. 53: 1177-1185, 2002.

Samani Majd S., Taebi A., Afyuni M.: [Lead and cadmium distribution in urban roadside soils of Isfahan, Iran.] J. Environ. Stud. 33: 1-10, 2007. [In Persian]

Sarangthem J., Jain M., Gadre R.: Inhibition of $\delta$-aminolevulinic acid dehydratase activity by cadmium in excised etiolated maize leaf segments during greening. - Plant Soil Environ. 57: 332-337, 2011.

Schreiber U., Schliwa U., Bilger W.: Continuous recording of photochemical and non-photochemical Chl fluorescence with a new type of modulation fluorometer. - Photosynth. Res. 10: 51-62, 1986.

Sękara A., Bączek-Kwinta R., Gawęda M. et al.: Sequential abiotic stress applied to juvenile eggplant modifies the seedlings parameters, plant ontogeny and field. - Hortic. Sci. 43: 149-157, 2016.

Sękara A., Poniedziałek M., Ciura J., Jędrszczyk E.: Cadmium and lead accumulation and distribution in the organs of nine crops: implications for phytoremediation. - Pol. J. Environ. Stud. 14: 509-516, 2005.

Shumaker K.L., Begonia G.: Heavy metal uptake, translocation, and bioaccumulation studies of Triticum aestivum cultivated in contaminated dredged materials. - Int. J. Environ. Res. Pu. 2: 293-298, 2005.

Sigfridsson K.G.V., Bernat G., Mamedov F., Styring S.: Molecular interference of $\mathrm{Cd}^{2+}$ with Photosystem II. - BBA- 
Bioenergetics 1659: 19-31, 2004.

Simmons R.W., Pongsakul P., Saiyasitpanich D., Klinphoklap S.: Elevated levels of cadmium and zinc in paddy soils and elevated levels of cadmium in rice grain downstream of a zinc mineralized area in Thailand: Implications for public health. Environ. Geochem. Hlth. 27: 501-511, 2005.

Sitko K., Rusinowski S., Kalaji H.M. et al.: Photosynthetic efficiency as bioindicator of environmental pressure in A. halleri. - Plant Physiol. 175: 290-302, 2017.

Sofo A., Dichio B., Montanaro G., Xiloyannis C.: Photosynthetic performance and light response of two olive cultivars under different water and light regimes. - Photosynthetica 47: 602-608, 2009.

Song X., Hu X., Ji P. et al.: Phytoremediation of cadmiumcontaminated farmland soil by the hyperaccumulator Beta vulgaris L. var. cicla. - B. Environ. Contam. Tox. 88: 623-626, 2012.

Szabó I., Bergantino E., Giacometti G.M.: Light and oxygenic photosynthesis: energy dissipation as a protection mechanism against photo-oxidation. - EMBO Rep. 6: 629-634, 2005.

Tang L., Yao A., Yuan M. et al.: Transcriptional up-regulation of genes involved in photosynthesis of the $\mathrm{Zn} / \mathrm{Cd}$ hyperaccumulator Sedum alfredii in response to zinc and cadmium. Chemosphere 164:190-200, 2016.

Vassilev A., Lidon F., Scotti P. et al.: Cadmium-induced changes in chloroplast lipids and photosystem activities in barley plants. - Biol. Plantarum 48: 153-156, 2004.

Wang H., Zhao S.C., Liu R.L. et al.: Changes of photosynthetic activities of maize (Zea mays L.) seedlings in response to cadmium stress. - Photosynthetica 47: 277-283, 2009.

Zhai L., Liao X., Chen T. et al.: Regional assessment of cadmium pollution in agricultural lands and the potential health risk related to intensive mining activities: a case study in Chenzhou City, China. - J. Environ. Sci. 20: 696-703, 2008.

Zhou W., Qiu B.: Effects of cadmium hyperaccumulation on physiological characteristics of Sedum alfredii Hance (Crassulaceae). - Plant Sci. 169: 737-745, 2005.

(C) The authors. This is an open access article distributed under the terms of the Creative Commons BY-NC-ND Licence. 